\title{
Five Eastern Peach Breeders
}

\author{
W.R. Okie ${ }^{1}$ \\ U.S. Department of Agriculture, Agricultural Research Service, Southeastern Fruit and Tree Nut Research Laboratory, \\ 21 Dunbar Road, Byron, GA 31008
}

Stone fruit breeding began about 100 years ago in the U.S. We are nearing the end of the careers of the third generation of breeders. This paper will cover five influential stone-fruit breeders, from the middle of the last century, who could be considered the second generation of breeders: Stanley Johnston, Catherine Bailey (and Fred Hough), Franklin Correll (and Carlyle Clayton), John Weinberger, and Ralph Sharpe.

\section{STANLEY JOHNSTON}

Stanley Johnston (1898-1969) (Fig. 1) was born in Roscommon, Mich., the son of an agricultural extension agent in Michigan. He went to Michigan State College (now Michigan State University), where he was active in many areas and was noted as an excellent college baseball player (American Society for Horticultural Science, 1966; Kessler, 1969). Although he received a MS in 1930 (thesis: "The Propagation of the Highbush Blueberry"), he had no formal genetics training. He was hired as superintendent of the South Haven Experiment Station in 1920, a position he held for the rest of his life.

As superintendent he was able to work on several crops that had potential for the area. $\mathrm{He}$

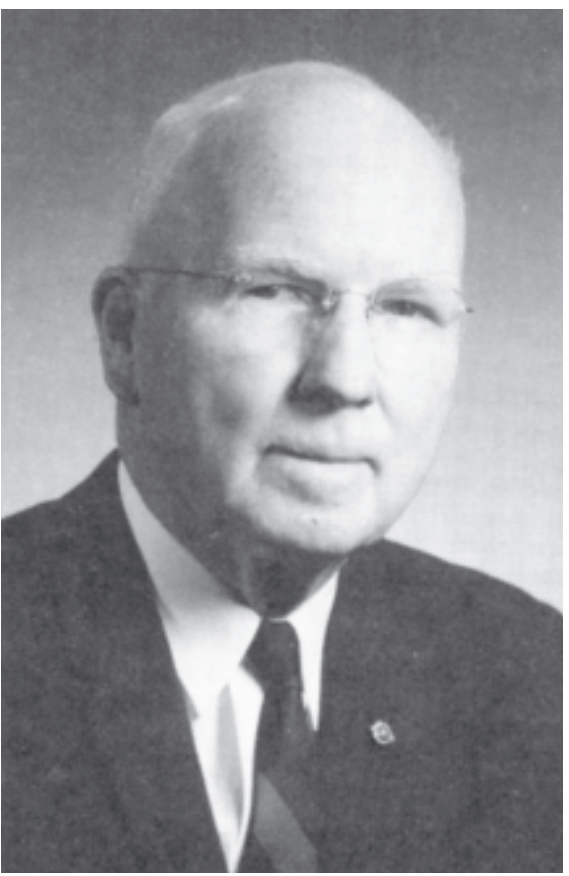

Fig. 1. Stanley Johnston.

\footnotetext{
II thank BobAndersen, Jim Ballington, Susan Brown, Frank Dennis, Joe Goffreda, Amy Iezzoni, David Ramming, Dave Ritchie, Wayne Sherman, Anna Voordeckers, and Dennis Werner for their help in preparing this paper.
}

and his colleagues collected germplasm, tested and bred pear, apricot (three releases), raspberry (one release), strawberry, and blueberry (four releases). He was instrumental in starting the blueberry industry in Michigan. With regard to peaches, he looked at the industry and saw too much 'Elberta'. There was market potential for early, firm, red peaches. He saved the seeds from pollination studies done to prove 'J.H. Hale' needed a pollinator, and from these made his first selections, resulting in the release of 'Halehaven' (1932) and 'Kalhaven' (1938). 'Redhaven' (1940) was the most important release and at one time was the most widely grown peach in the world (Iezzoni, 1987). Later releases included 'Fairhaven', 'Sunhaven', 'Richhaven', 'Glohaven', and 'Cresthaven'. Surprisingly he grew only 27,000 seedlings over a 40 -year career. He may be the only breeder with an historical marker commemorating his work.

Johnston was very dedicated to the farmer, perhaps due to his extension background, and looked for practical solutions. He had a clear understanding of their needs. One advantage he had was his friendship with John Hannah, who advanced from poultry science extension to president of the college, and who supported the breeding work. Johnston was a family man (two children) and also quite active in the community, serving on many civic boards, including the Board of Education, Hospital Board, and as a longtime member of Kiwanis.

\section{CATHERINE BAILEY}

Catherine Hayes Bailey (born in 1921) (Fig. 2) was the daughter of the superintendent of

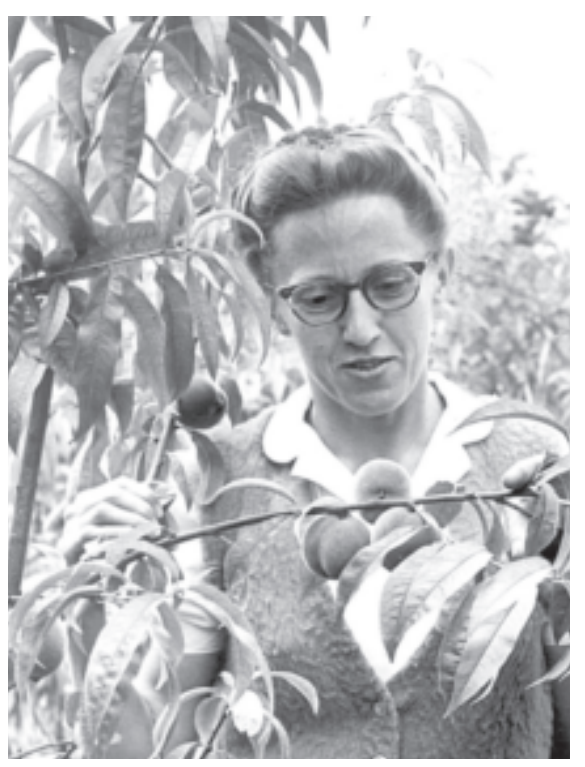

Fig. 2. Catherine Bailey. the Rutgers Vegetable Farm. Appropriately, she attended Douglas College (now part of Rutgers University) and received a BS. In the 1940s she began working as a technician in the breeding program of Maurice Blake, who was nearing the end of his career as stone-fruit breeder at Rutgers. She kept the program running between breeders, as Fred Hough arrived in 1948. At that time the main crops were peach and apple. Hough encouraged her to get a $\mathrm{PhD}$ at Rutgers in fruit breeding, which she finished in 1957 (dissertation: "Inheritance of Season of Ripening in Progenies from Certain Early Ripening Peach Cultivars and Selections"), making her the only female faculty member in the department. On paper she headed stone fruit and Hough headed pome fruit, but in practice it was a team effort. Hough (discussed further under apples) was the visionary and traveler, while she was content to work more in the background. They began breeding nectarine and apricot to develop new industries for the state, although the apricot releases such as 'OrangeRed' have been more successful in Europe than at home; the New Jersey industry is still modest, awaiting further improvement in cultivar adaptation (Bailey, 1971; Mehlenbacher, 1986). The Nectared series of nectarines provided adapted cultivars but, again, the climate keeps the industry small.

In the peach breeding program, the use of embryo culture allowed advances in earliness. The large germplasm collection provided raw material for new types, resulting in firm, white peaches and flat peaches such as 'Saturn'. With a large crew of graduate students (one of the biggest worldwide legacies of this project), there were many crosses and selections made, resulting in important cultivars released such as 'Encore' and 'Jerseyland' (Mehlenbacher, 1986). Equally important were the large populations that were generated and thousands of seed sent around the world to help other breeders. When John Weinberger retired from U.S. Department of Agriculture-Fresno in 1973, she applied for his position. Although clearly well-qualified, she was not selected in favor of one of her students, David Ramming, perhaps reflecting the difficulties facing a woman scientist in those days.

Bailey was very dedicated to the research and well-suited to be the glue that held the project together. She was a highly organized, no-nonsense worker, not prone to jumping rows as her partner did when something exciting appeared a few rows over. She often out-worked her graduate students, getting by on sips of her lemonade rather than gallons of water. Her passions off the job were the Baptist church, photography, and bird-watching. As she worked the rows in the orchard, she could identify many of the birds by song. She 


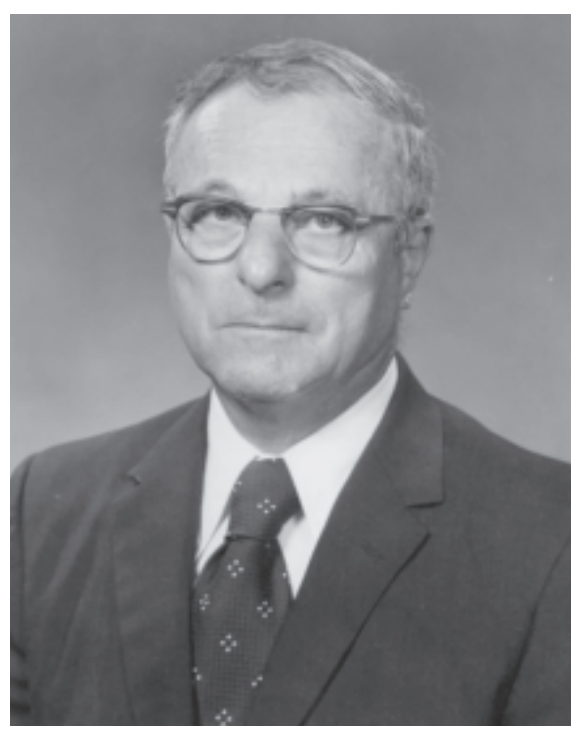

Fig. 3. Franklin Corell.

remained unmarried, living with her parents until they died. She is now living in retirement in Vermont.

\section{FRANKLIN CORRELL}

Franklin E. Correll, Jr. (1913-1974) (Fig. 3), was born in Woodleaf, N.C. He attended North Carolina (NC) State University and ultimately received an MS degree, doing his research on blueberries (thesis: "The Effects of Self- vs. Cross-pollination on Pentaploid Blueberries"). In 1955 he was hired to start a peach-breeding program at NC State. About 10 years earlier, Carlyle Clayton had been hired as a fruit pathologist (Sutton and Ritchie, 1999). Clayton had a good horticulture background and was very active in the efforts to help growers. His was a rare combination of scientific interest and practical skills that allowed him to solve real-world problems. It was apparent to him that the peach industry needed cultivars resistant to bacterial spot disease if it was going to thrive on the state's sandy soils. After Correll was hired, the two cooperated in one of the first cross-discipline team efforts to develop disease-resistant tree fruit. Although their cultivars were not widely grown outside North Carolina, the project was successful and their close cooperation was a model for others coming after them.

Franklin Correll had an affinity for lab work and enjoyed that side of the project. As a result, he also put great emphasis on resistance to flesh browning as a project goal. He was successful in developing a series of spot resistant peach cultivars, the most resistant of which were 'Clayton' and 'Candor' (Werner and Ritchie, 1982). Other popular cultivars were 'Norman', 'Winblo', and 'Biscoe' (Werner and Ritchie, 1982). Although peaches were his main interest, he continued to do some breeding with blueberries as well.

Correll had a quiet temperament and kind personality. He was dedicated to peach breeding and development of improved peaches. To accomplish this, he tirelessly kept to a methodical, demanding schedule. During the 2 months that the peaches ripened, Correll and his assistants would make the 3-hour round trip drive from Raleigh to the breeding plots at the Sandhill Station each Monday, Wednesday, and Friday. The long days were only broken up by lunch at the Candor Café. Fruit were brought back for flesh-browning analyses that were done on Tuesday and Thursday. The only things that deterred Correll from this routine was a crop loss due to spring frost and his early death from cancer in 1974 while still working on the project. Clayton continued to work with fruit and even had an 80 acre fruit farm with peaches, apples, and grapes after he retired in 1978. He died in 1998

\section{JOHN WEINBERGER}

John Howard Weinberger (1907-1999) (Fig. 4) was born in New York City, but was raised on a fruit farm in eastern Pennsylvania (American Society for Horticultural Science, 1974; Childers and Sherman, 1988; Ramming and Fear, 1993). He obtained a BS from Pennsylvania State and a $\mathrm{PhD}$ from the University of Maryland (dissertation: "Effect of Various Potash Fertilizers on the Firmness and Keeping Quality of Apples, Peaches and Strawberries"). After a few years at Beltsville working in physiology, he was assigned to the Agricultural Research Service (ARS) laboratory at Fort Valley, Ga., in 1937 to develop new peaches and rootstocks (Okie et al., 1985). In 1954 he transferred to ARS-Fresno, where he added apricots, plums, and grapes (inheriting earlier work by E. Snyder and F.N. Harmon to develop seedless table grapes) to his efforts. His rootstock work resulted in the root-knot-resistant cultivars 'Nemaguard' and 'Nemared'. 'Castlebrite' apricot was widely grown because it was the earliest ripening, firm and attractive apricot available at the time. 'Friar' plum was the first major black-skinned plum, although red plums were the standard at that time, and black ones were not thought to have market potential. 'Friar', along with 'Blackamber' (which he bred, selected and trialed but D. Ramming finished evaluating), have made up more than $25 \%$ of the California fresh-market

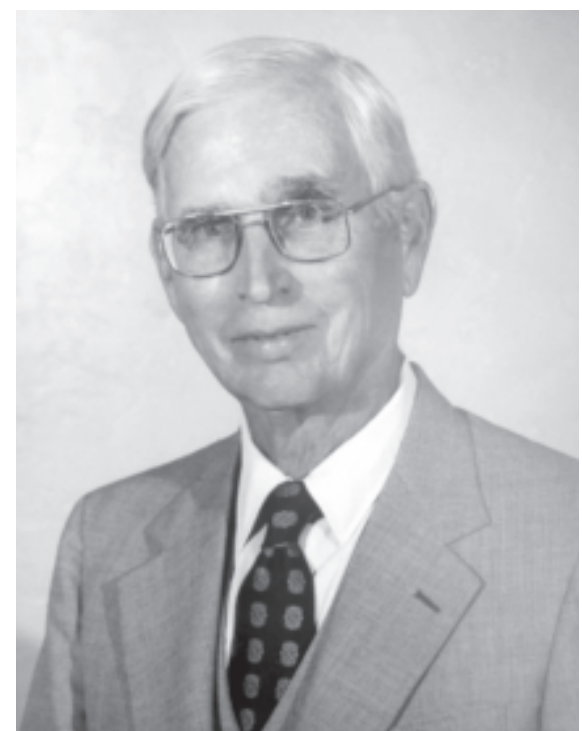

Fig. 4. John Weinberger. plum production for over the last 10 years. And, of course, 'Flame Seedless' grape, the first seedless ARS release, has been one of the best fruit releases of the last century. After retiring from the ARS in 1973, he continued to work as a breeding consultant for Superior Farming/SunWorld in Bakersfield, Calif. He retired a second time in 1988 .

Although Weinberger grew relatively few seedlings (about 4000 total stone fruit per year in Fresno), he had clear goals in mind and a discerning eye to find the best in his material. His training in physiology helped him to "know his organism." His experience in the northeastern, southeastern, and western U.S. gave him a unique perspective on fruit adaptation. Although he only published a few papers, they were important ones (such as those on chilling) that revealed him to be a keen observer and thoughtful scientist. As a breeder he took careful notes but did not look back once a decision was made. He had a great rapport with growers and conducted many on-farm trials with them. His peach and nectarine legacy is great and includes 'Cardinal', 'Dixired', 'Flavorcrest', 'Fayette', 'Redtop', FV89-14 (parent of 'Springcrest' and many other peaches), 'Firebrite', and 'Flavortop'.

Weinberger worked hard but efficiently; he did not take it home with him. He was more interested in the breeding work than in advancing up the ranks. He was a faithful Presbyterian, a dedicated family man who enjoyed life and had a dry sense of humor. As with many successful breeders, he enjoyed excellent technical help, including secretary Mary Tappe and fruit technician Owen Tanner.

\section{RALPH SHARPE}

Ralph Harold Sharpe (1913-2004) (Fig. 5) was born on a farm in Pennsylvania. He went to Pennsylvania State University for a BS and Texas A\&M University for a MS (thesis: "A Study of Certain Growth and Fruiting Responses of the Pecan") in 1938. After working at the tung research station in Louisiana, in 1948 he joined the fruit crops faculty at University of Florida to work on pecan nutrition. Although he had no breeding background Ralph had a wide range of interests. He soon began working with peaches and blueberries, realizing that no existing low-chill cultivars were suitable for commercial production, but that improved adapted cultivars were needed to develop an industry (Sharpe, 1970; Sherman and Lyrene, 1991). The blueberry work included releases 'Flordablue' and 'Sharpblue' and has resulted in a thriving industry. He also worked with blackberries ('Flordagrande') as well as various subtropical crops.

Sharpe had a good eye for variability. The peach and nectarine breeding $(40,000$ seedlings from 1952-1970) resulted in important low-chill cultivars such as 'Flordasun', 'Flordaqueen', and 'Flordawon' peaches and 'Sunrich' and 'Sunlite' nectarines. Although these suffered from quality problems, they demonstrated the feasibility of a low-chill industry and were themselves a big improvement over the founding materials such as 'Okinawa', 


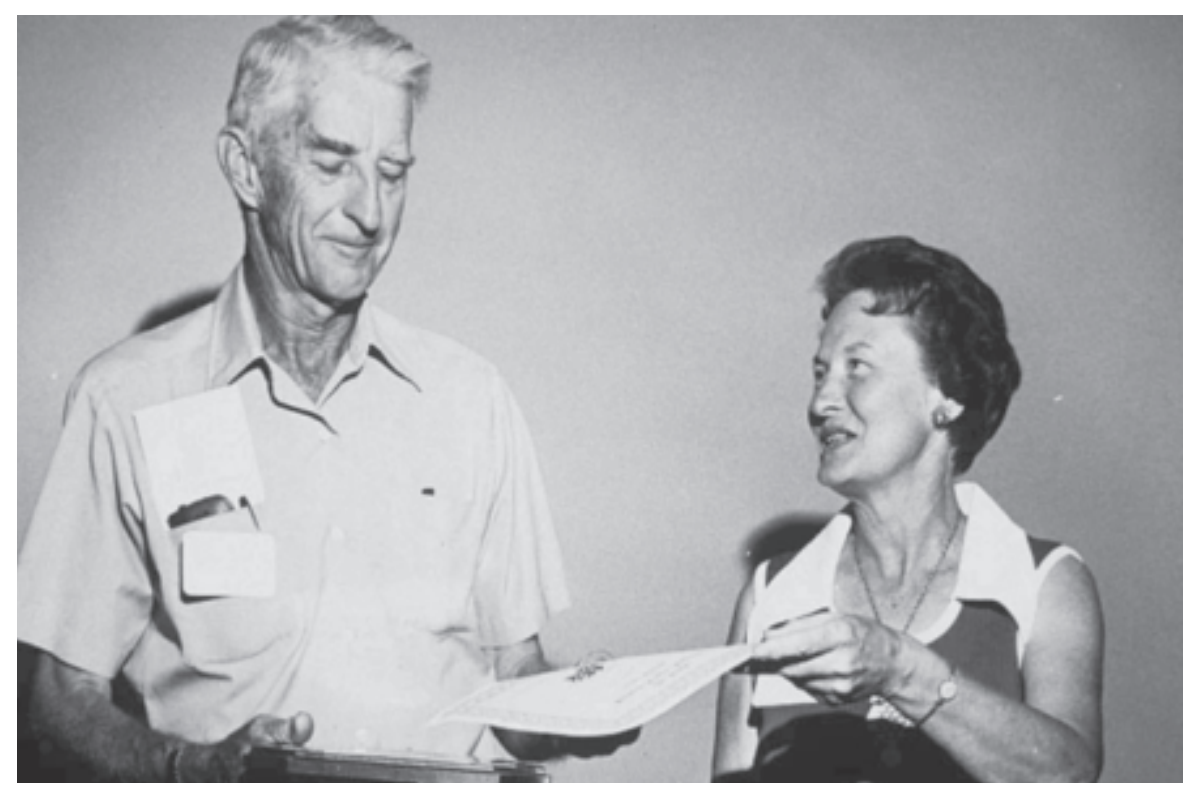

Fig. 5. Ralph Sharpe receiving an award from Vivian Hansen, first president of the Florida Blueberry Growers' Association, Gainesville, in about 1976.

which he introduced as a source of ultra-lowchill genes. Considering that the commercial parents available to him were cultivars we now consider substandard relative to modern improved cultivars, he made much progress. His releases and the subsequent Florida germplasm have been the basis for breeding and production of low-chill peaches worldwide (Sherman and Lyrene, 1991). Efforts to develop a low-chill, root-knot-nematode-resistant rootstock that could be used in Florida resulted in the eventual release of 'Flordaguard'.

Sharpe enjoyed life and his family, and he particularly loved to fish. He had a broad range of interests and was active and enthusiastic even late into life. After he retired in 1975 he continued to assist in the breeding program and anywhere else he could be of service. When he was in his 80 s he ran a small business on the side collecting old bicycles left behind by departing students, repairing them as needed, and selling them or giving them to a worthy home the next fall. factors are appropriate to having an impact. Vision is the ability to see what is needed and what is feasible. Passion is the devotion to the job both daily and over the years, the willingness and ability to work for a distant payoff. Discipline is being able to keep in mind and execute the many steps to get there in an efficient way. Risk is the willingness to release your embodiment of the vision, which must then make it on its own in the orchard and market, but which might also fail.

\section{Literature Cited}

American Society for Horticultural Science. 1966. Personnel notes - Stanley Johnston. HortScience 1:111 (and cover).

American Society for Horticultural Science. 1974. Personnel notes-John Weinberger. HortScience 9:2.

Bailey, C.H. 1971. What's new in peach varieties for the Northeast. Proc. Nat. Peach Council 113-115.

Childers, N. and W.B. Sherman. 1988. John Howard Weinberger, p. 2. In: The peach. Horticultural Publications, Gainesville, Fla.

Iezzoni, A.F. 1987. The 'Redhaven' peach. Fruit Var. J. 41:50-52.

Kessler, G.M. 1969. Stanley Johnston(1898-1969). Fruit Var. Hort. Dig. 23:37-38

Although these five breeders were different and had their own strengths and weaknesses, several characteristics stand out. Most had farm backgrounds, not uncommon in their day. Most learned breeding on the job rather than in graduate school. Most had good rapport with growers and did some extension work; they were applied problem-solvers. They wrote few papers but were more aimed at cultivar development. They had excellent technical support, without which breeding is difficult. All were dedicated to the job and stayed at one place a long time, which is necessary to have an impact in tree-fruit breeding. Surprisingly, at least three of them also worked with blueberries, perhaps reflecting a common vision that there was a bright future for this crop.

Some have suggested there are four characteristics that enable one to be influential in the best sense off the word. Although not originally referring to the world of plant breeding, these
Mehlenbacher, S.A. 1986. The New Jersey peach breeding program, p. 69-73. Proc. Natl. Peach Council.

Okie, W.R., D.W. Ramming, and R. Scorza. 1985. Peach, nectarine and other stone fruit breeding by the USDA in the last two decades. HortScience 20:633-641.

Ramming, D.W. and C.D. Fear. 1993. John H. Weinberger-Fruit breeder and horticulturalist. Plant Breed. Rev. 11:1-10.

Sharpe, R. 1970. Sub-tropical peaches and nectarines. Fla. State Hort. Soc. 82:302-306.

Sherman, W.B. and P.M. Lyrene. 1991. Deciduous fruit cultivar improvement in Florida. HortScience 26:2, 91 .

Sutton, T.B. and D.F. Ritchie. 1999. Carlyle Newton Clayton. Phytopathology 89:532.

Werner, D.J. and D.F. Ritchie. 1982. Peach cultivars introduced by the North Carolina Agricultural Research Service 1965 to 1981. N.C. State Agr. Res. Serv. Sta. Bul. 464. 